Received: 4 July 2017

Accepted: 8 November 2018

Published online: 27 November 2018

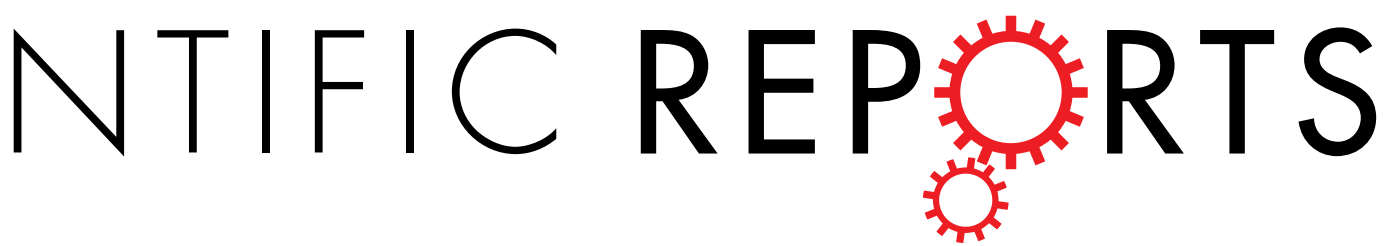

\title{
OPEN The Invisible Carbon Footprint as a hidden impact of peatland degradation inducing marine carbonate dissolution in Sumatra, Indonesia
}

\begin{abstract}
Francisca Wit ${ }^{1}$, Tim Rixen ${ }^{1,2}$, Antje Baum ${ }^{1}$, Widodo S. Pranowo $\mathbb{D}^{3}$ \& Andreas A. Hutahaean ${ }^{4}$
In Indonesia, land use change (LUC) in the form of peatland degradation induces carbon loss through direct $\mathrm{CO}_{2}$ emissions, but also via soil leaching of which circa $50 \%$ is decomposed and emitted as $\mathrm{CO}_{2}$ from the rivers. However, the fate of the remaining exported leached carbon is uncertain. Here, we show that the majority of this carbon is respired in the estuaries and emitted to the atmosphere. However, a portion is adsorbed into the marine carbon pool where it favors $\mathrm{CaCO}_{3}$ dissolution and can therefore be seen as the invisible carbon footprint. We conclude that the effects of LUC stretch beyond the terrestrial realm and are not limited to $\mathrm{CO}_{2}$ emissions, but also affect marine ecosystems. Considering the ecological and economical importance of these ecosystems, it is important that this so far invisible carbon footprint, as well as the aquatic and marine $\mathrm{CO}_{2}$ emissions, are included in climate mitigation strategies.
\end{abstract}

Peatland degradation in Southeast Asia is recognized as an important carbon source to the atmosphere ${ }^{1}$ albeit so far not yet considered in all global estimates of $\mathrm{CO}_{2}$ emissions. It would increase the LUC emissions from 1100 $\mathrm{Tg} \mathrm{C} \mathrm{yr}^{-1}$ (ref. $^{2}$ ) to $1389 \pm 938 \mathrm{Tg} \mathrm{C} \mathrm{yr}^{-1}$ (26\%) only by considering $\mathrm{CO}_{2}$ emissions caused by peat oxidation and forest fires $\left(289 \pm 138 \mathrm{Tg} \mathrm{C} \mathrm{yr}^{-1}\right)\left(\right.$ ref. $\left.^{3}\right)$. In Indonesia, regrowth of secondary vegetation could reduce this $\mathrm{CO}_{2}$

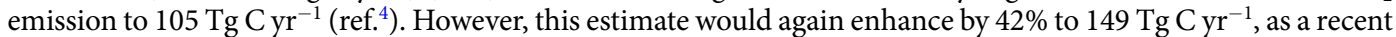
study ${ }^{5}$ revealed that degradation of peatlands has increased carbon leaching from soils by $200 \%$ with a leaching rate of $183 \mathrm{~g} \mathrm{C} \mathrm{m}^{-2} \mathrm{yr}^{-1}$, as opposed to $62 \mathrm{~g} \mathrm{C} \mathrm{m}^{-2} \mathrm{yr}^{-1}$ from pristine peatlands ${ }^{6}$. This increase results partly from changes in the hydrological cycle due to drainage (38\%), but is primarily due to regrowth of secondary vegetation $(62 \%)$ with leaves consisting of relatively labile organic carbon. Despite the carbon-enriched peat soils and enhanced leaching rate, the location of the peatlands near the coast limits the decomposition of leached carbon in the rivers by reducing its residence time in the river, which leads to a relatively modest river outgassing rate of 21-25 $\mathrm{Tg} \mathrm{C} \mathrm{yr}^{-1}\left(87-109 \mathrm{~g} \mathrm{C} \mathrm{m}^{-2} \mathrm{yr}^{-1}\right)$ in Indonesian disturbed peatlands ${ }^{5,7}$. With roughly half of the carbon that enters the freshwater system being decomposed and emitted into the atmosphere, it remains unclear what the fate of the exported riverine carbon is once it has reached the estuaries and coastal ocean. In general, tropical estuaries and coastal oceans are heterotrophic systems emitting $\mathrm{CO}_{2}{ }^{8-10}$. In contrast, a recent study ${ }^{11}$ shows that coastal oceans in west Southeast Asia are considered to be a carbon sink, which would imply that the carbon that is leached from peat soils and exported via the rivers to the coastal ocean is absorbed in the water column.

In this study, we aim to resolve these knowledge gaps in Sumatra, Indonesia, by quantifying the riverine carbon export and investigate the estuarine and marine processes to better understand the fate of terrestrial carbon in the coastal ocean.

${ }^{1}$ Leibniz Center for Tropical Marine Research (ZMT), Fahrenheitstrasse 6, 28359, Bremen, Germany. ${ }^{2}$ Institute of Geology, University of Hamburg, Bundesstrasse 55, 20146, Hamburg, Germany. ${ }^{3}$ Research \& Development Center for Marine \& Coastal Resources (P3SDLP), Gedung II BALITBANGKP, Jalan Pasir Putih II, Ancol Timur, Jakarta, 14430, Indonesia. ${ }^{4}$ Coordinating Ministry of Maritime Affairs, Jalan. MH. Thamrin No. 8, Jakarta, 10340, Indonesia. Correspondence and requests for materials should be addressed to F.W. (email: fmc.wit@gmail.com) 


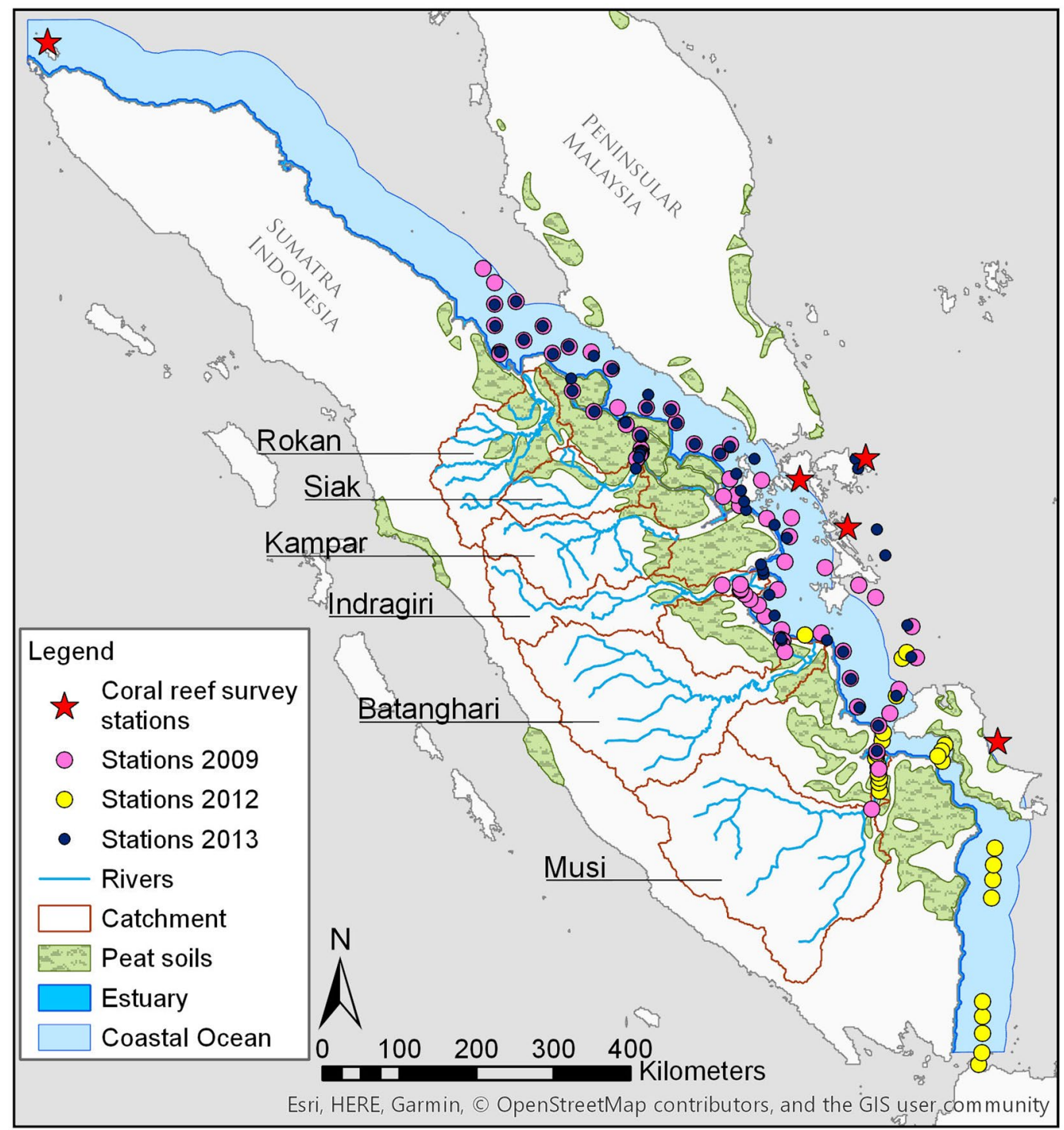

Figure 1. Study area and sample stations in 2009, 2012 and 2013 along the coast of Sumatra, Indonesia. The map was drawn using ArcGIS 10.4.1 by ESRI (http://desktop.arcgis.com/en/).

\section{Results and Discussion}

Riverine carbon processes and exports. Tropical peatlands in Sumatra cover approximately $15.6 \%{ }^{12}$ or $72,431 \mathrm{~km}^{2}$ of the land area with a thickness between 2 and $10 \mathrm{~m}^{13}$ and are mostly located on the coastal plains. The large majority of these peatlands is disturbed as a consequence of deforestation and drainage to make way for agricultural cropland and in particular palm oil plantations ${ }^{12}$, with only a small portion (6\%) of pristine tropical peatlands remaining in Southeast $\mathrm{Asia}^{14}$. A total of three expeditions were carried out along the north and east coast of Sumatra in October 2009, October 2012 and April 2013, with 72, 32 and 57 sampling stations, respectively. Six rivers were investigated, namely the Musi, Batanghari, Indragiri, Kampar, Siak and Rokan (Fig. 1), of which the river catchments contain various amounts of peatland coverage, ranging from $3.5 \%$ in the Musi up to $30.2 \%$ in the Rokan catchment (Table 1). Through leaching, carbon is mobilized from the peat soils into the rivers, which is further enhanced through disturbance ${ }^{6}$ and the labile content of the leaves of secondary vegetation ${ }^{5}$. The export ratio between total organic carbon and total inorganic carbon (TOC:TIC) increases with increasing peat coverage as the overlying peat soils leach organic carbon and simultaneously reduce the contribution of dissolved (inorganic) carbonate derived from weathering of underlying mineral soils to the rivers ${ }^{15,16}$. The relative importance of dissolved inorganic carbon (DIC) derived from respiration and silicate weathering can also be quantified by $\delta^{13} \mathrm{C}_{\mathrm{DIC}}$. The riverine $\delta^{13} \mathrm{C}_{\mathrm{DIC}}$ is a mixture between low $\delta^{13} \mathrm{C}_{\mathrm{CO} 2}$ values from decomposed plant material, which amounts to an average of $-28.0 \pm 1.5 \%$ as derived from leached terrestrial dissolved organic carbon (DOC) measured in the Siak, Rokan and Kampar rivers in 2006, and $\mathrm{HCO}_{3}{ }^{-}$derived from weathering of mineral soils ${ }^{17}$, which have an isotopic signature of about $0 \%{ }^{18}$. The Siak river has a $\delta^{13} \mathrm{C}_{\mathrm{DIC}}$ of $-22.5 \%$ derived from decomposed terrestrial DOC and less from weathering and its DIC is composed primarily of $\mathrm{CO}_{2}$ (Fig. 2a, Table 1 and 


\begin{tabular}{|c|c|c|c|c|c|c|c|c|}
\hline \multicolumn{2}{|l|}{ Location } & \multirow{2}{*}{\begin{tabular}{|l|} 
Musi \\
56931 \\
\end{tabular}} & \multirow{2}{*}{$\begin{array}{l}\text { Batanghari } \\
44890\end{array}$} & \multirow{2}{*}{$\begin{array}{l}\text { Indragiri } \\
17968\end{array}$} & \multirow{2}{*}{$\begin{array}{l}\text { Kampar* } \\
26195\end{array}$} & \multirow{2}{*}{\begin{tabular}{|l|} 
Siak \\
10423 \\
\end{tabular}} & \multirow{2}{*}{\begin{tabular}{|l|} 
Rokan* \\
19258 \\
\end{tabular}} & \multirow{2}{*}{$\begin{array}{l}\text { Sumatra* } \\
464301\end{array}$} \\
\hline Catchment & $\mathrm{km}^{2}$ & & & & & & & \\
\hline River area & $\mathrm{km}^{2}$ & 245 & 269 & 174 & 210 & 81 & 154 & 3714 \\
\hline Discharge & $\mathrm{m}^{3} \mathrm{~s}^{-1}$ & $3961 \pm 587$ & $2309 \pm 182$ & $1339 \pm 89$ & $2063 \pm 297$ & $720 \pm 74$ & $1506 \pm 307$ & $31820 \pm 3606$ \\
\hline Peat cover & $\%$ & 3.5 & 5 & 11.9 & 22.4 & 21.9 & 30.2 & 15.6 \\
\hline Peat cover & $\mathrm{km}^{2}$ & 1993 & 2245 & 2138 & 5868 & 2283 & 5816 & 72431 \\
\hline$\delta^{13} \mathrm{C}_{\mathrm{DIC}}$ & $\%$ & -9.0 & - & -16.8 & - & -22.5 & - & - \\
\hline $\mathrm{CO}_{2 \text {-DIC }}$ & $\%$ & \begin{tabular}{|l|}
17.1 \\
\end{tabular} & - & 41.9 & - & 88.3 & - & - \\
\hline $\mathrm{HCO}_{3 \text {-DIC }}$ & $\%$ & 82.7 & - & 58.0 & - & 11.7 & - & - \\
\hline $\mathrm{CO}_{3}{ }^{2-}$ DIC & $\%$ & 0.2 & - & 0.0 & - & 0.0 & - & - \\
\hline DOC conc. & $\mu \mathrm{M}$ & $303 \pm 61$ & $311 \pm 39$ & \begin{tabular}{|l|}
$757 \pm 99$ \\
\end{tabular} & $1280 \pm 63$ & $1900 \pm 640$ & $781 \pm 53$ & $890 \pm 159$ \\
\hline DOC yield & $\mathrm{gC} \mathrm{m}^{-1} \mathrm{yr}^{-1}$ & $8.00 \pm 3.91$ & $6.05 \pm 0.62$ & $21.37 \pm 4.99$ & $32.65 \pm 0.88$ & $49.71 \pm 27.26$ & $23.13 \pm 3.09$ & $23.09 \pm 6.79$ \\
\hline DOC flux & $\operatorname{Tg} \mathrm{C} \mathrm{yr}^{-1}$ & $0.46 \pm 0.22$ & $0.27 \pm 0.03$ & $0.38 \pm 0.09$ & $0.86 \pm 0.02$ & \begin{tabular}{|l|}
$0.52 \pm 0.28$ \\
\end{tabular} & $0.45 \pm 0.06$ & $10.72 \pm 0.12$ \\
\hline DIC conc. & $\mu \mathrm{M}$ & $748 \pm 42$ & $671 \pm 21$ & $409 \pm 12$ & $294 \pm 21$ & $291 \pm 11$ & $333 \pm 21$ & $483 \pm 137$ \\
\hline DIC yield & $\mathrm{gC} \mathrm{m}^{-1} \mathrm{yr}^{-1}$ & $19.71 \pm 0.16$ & $13.08 \pm 0.03$ & $11.53 \pm 0.02$ & $7.49 \pm 0.09$ & $7.62 \pm 0.03$ & $9.86 \pm 0.13$ & $12.53 \pm 0.40$ \\
\hline DIC flux & ${\mathrm{TgC} \mathrm{yr}^{-1}}^{-1}$ & $1.12 \pm 0.01$ & $0.59 \pm 0.00$ & $0.21 \pm 0.00$ & $0.20 \pm 0.00$ & $0.08 \pm 0.00$ & $0.19 \pm 0.00$ & $5.82 \pm 0.19$ \\
\hline POC conc. & $\mu \mathrm{M}$ & $143 \pm 51$ & $109 \pm-$ & $482 \pm 113$ & $156 \pm 39$ & $499 \pm 109$ & $1034 \pm 18$ & $404 \pm 55$ \\
\hline POC yield & $\mathrm{gC} \mathrm{m}^{-1} \mathrm{yr}^{-1}$ & $3.76 \pm 0.20$ & $2.12 \pm-$ & $13.60 \pm 0.21$ & $3.98 \pm 0.17$ & $13.06 \pm 0.29$ & $30.64 \pm 0.11$ & $10.48 \pm 0.16$ \\
\hline POC flux & $\operatorname{Tg} \mathrm{C} \mathrm{yr}^{-1}$ & $0.21 \pm 0.01$ & $0.10 \pm 0.00$ & $0.24 \pm 0.00$ & $0.10 \pm 0.00$ & $0.14 \pm 0.00$ & $0.59 \pm 0.00$ & $4.87 \pm 0.08$ \\
\hline PIC conc. & $\mu \mathrm{M}$ & $8 \pm 0.17$ & $10 \pm 0.20$ & $57 \pm 1.14$ & - & $0 \pm 0.00$ & - & $19 \pm 0.38$ \\
\hline PIC yield & $\mathrm{gC} \mathrm{m}^{-1} \mathrm{yr}^{-1}$ & $0.22 \pm 0.00$ & $0.20 \pm 0.00$ & $1.60 \pm 0.00$ & - & $0.00 \pm 0.00$ & - & $0.49 \pm 0.00$ \\
\hline PIC flux & $\operatorname{TgC~} \mathrm{yr}^{-1}$ & $0.01 \pm 0.00$ & $0.01 \pm 0.00$ & $0.03 \pm 0.00$ & - & $0.00 \pm 0.00$ & - & $0.23 \pm 0.00$ \\
\hline TOC exp. & $\mathrm{Tg} \mathrm{C} \mathrm{yr}^{-1}$ & $0.67 \pm 0.23$ & $0.37 \pm 0.03$ & $0.63 \pm 0.09$ & $0.96 \pm 0.03$ & $0.65 \pm 0.29$ & $1.04 \pm 0.06$ & $15.59 \pm 0.19$ \\
\hline TIC exp. & $\mathrm{Tg} \mathrm{C} \mathrm{yr}^{-1}$ & $1.13 \pm 0.01$ & $0.60 \pm 0.00$ & $0.24 \pm 0.00$ & $0.20 \pm 0.00$ & $0.08 \pm 0.00$ & $0.19 \pm 0.00$ & $6.04 \pm 0.19$ \\
\hline TC exp. & Tg C yr ${ }^{-1}$ & $1.80 \pm 0.24$ & $0.96 \pm 0.03$ & $0.86 \pm 0.09$ & $1.16 \pm 0.03$ & $0.73 \pm 0.29$ & $1.23 \pm 0.06$ & $21.63 \pm 0.38$ \\
\hline $\mathrm{CO}_{2}: \mathrm{C}_{\exp }$ ratio & - & $27: 73$ & $29: 71$ & $43: 57$ & $52: 48$ & $38: 62$ & $49: 51$ & $43: 57$ \\
\hline OC:IC ratio & - & $37: 63$ & $38: 62$ & $73: 27$ & $83: 17$ & $89: 11$ & $85: 15$ & $72: 28$ \\
\hline
\end{tabular}

Table 1. Carbon export rates from rivers in Sumatra based on averaged concentrations measured during expeditions from 2009 to 2013, including POC and PIC data from cruises in 2004, 2005, 2006 and 2008. Errors are represented as the standard error. *DIC concentrations for the Kampar, Rokan and Sumatra were derived from the correlation between DIC concentrations and peat coverage of the Musi, Batanghari and Siak rivers.

Supplementary Fig. 1). In the Musi and Indragiri, which have smaller relative peat coverages, $\delta^{13} \mathrm{C}_{\text {DIC }}$ values are higher with $-16.8 \%$ and $-9.0 \%$, respectively, which indicates that mineral soil weathering plays a more active role in these catchments.

The dissolved and particulate organic and inorganic riverine carbon fluxes have been calculated based on measurements carried out between 2004 and 2013 (Supplementary Table 1) and were interpolated to encompass Sumatra. Exports were calculated by multiplying the average carbon end-member concentration with discharge, which was based on averaged monthly precipitation rates (Supplementary Table 1) and assuming an evapotranspiration rate of $37.9 \%{ }^{6}$. DOC and DIC end-member concentrations per expedition were derived through correlating their concentrations with salinity, where the $y$-intercept at salinity 0 represents the end-member concentration. DIC concentrations $\left(\mu \mathrm{mol} \mathrm{kg}{ }^{-1}\right.$ ) were calculated using the co2sys program with total alkalinity (TA) and $\mathrm{pCO}_{2}$ measurements as input parameters, alongside other required inputs of salinity, temperature, pressure and nutrient measurements. Particulate organic carbon (POC) and particulate inorganic carbon (PIC) concentrations were derived from stations in a salinity range of $0-1$, as it was not possible to obtain an end-member due to few data points. Exports normalized to catchment area represent the yield.

On average $72 \%$ of the exported carbon from Sumatra is organic with $10.72 \pm 0.12 \mathrm{Tg} \mathrm{C} \mathrm{yr}^{-1}$ of DOC and

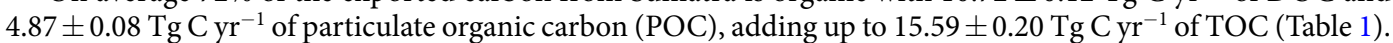
The export of TIC amounts to $6.05 \pm 0.19 \mathrm{Tg} \mathrm{C} \mathrm{yr}^{-1}$, mostly consisting of DIC with $5.82 \pm 0.19 \mathrm{Tg} \mathrm{C} \mathrm{yr}^{-1}$, whereas

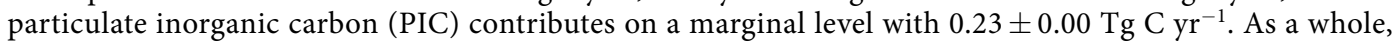
Indonesia, with a peat coverage of $11.9 \%$ or $2.3 * 10^{5} \mathrm{~km}^{2}$ (ref. ${ }^{7}$ ), has a TOC export of $53.06 \mathrm{Tg} \mathrm{C} \mathrm{yr}^{-1}$ and a TIC

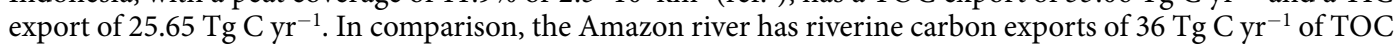

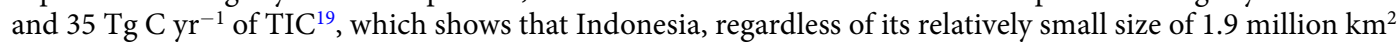
(ref. ${ }^{7}$ ) compared to the Amazon catchment of 3.9 million $\mathrm{km}^{2}$ (ref. ${ }^{19}$ ), plays a crucial role with respect to carbon exports. Its relatively large riverine export of organic carbon shifts the attention to the fate of this organic carbon in the estuaries.

Carbon fluxes and processes in the estuaries and coastal ocean. As river waters reach the estuaries and coastal ocean of Sumatra, $\mathrm{pCO}_{2}$ levels rapidly decrease. In order to investigate to which extent mixing with low $\mathrm{pCO}_{2}$ ocean waters is responsible for this measured decrease, $\mathrm{pCO}_{2}$ mixing lines were calculated. In the estuaries, TA and DIC concentrations increase in a linear fashion as low concentration river waters mix with high 


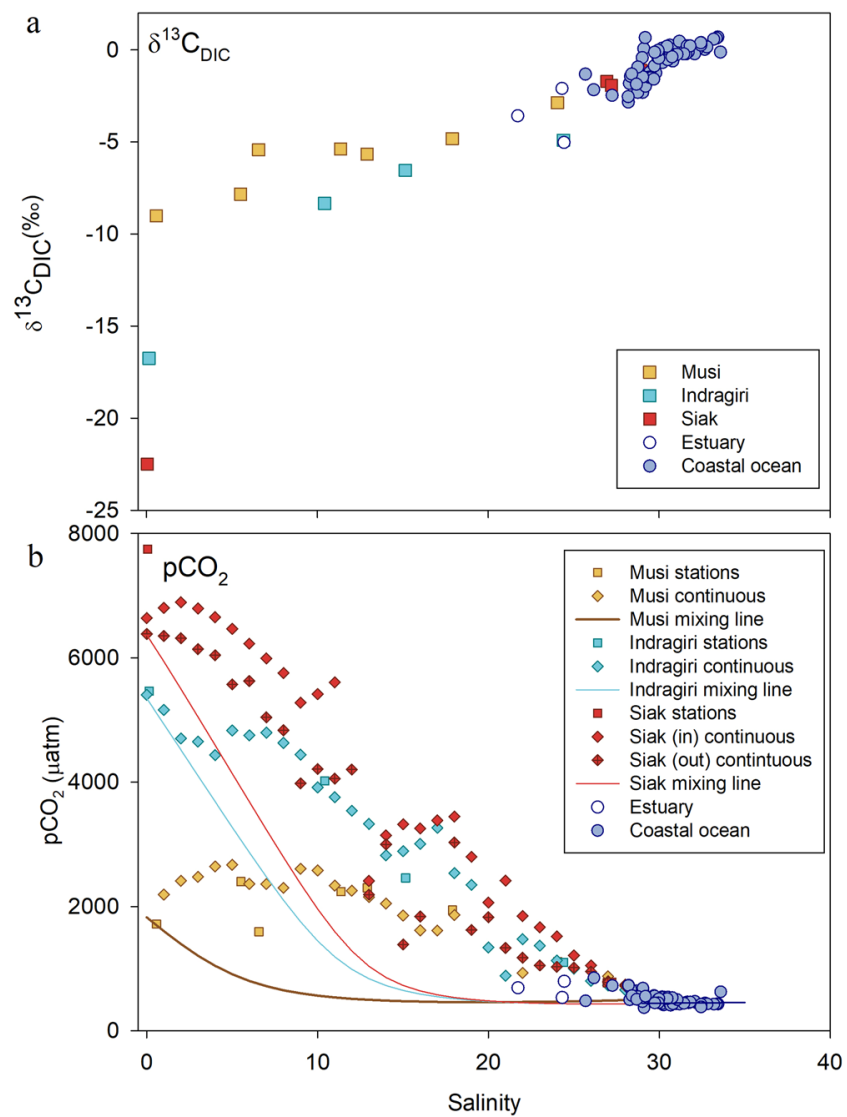

Figure 2. (a) $\delta^{13} \mathrm{C}_{\mathrm{DIC}}$ values plotted against salinity. (b) Measured $\mathrm{pCO}_{2}$ concentrations (dots) and expected $\mathrm{pCO}_{2}$ concentrations during mixing in the estuaries (mixing lines). To complement the figure with respect to $\mathrm{pCO}_{2}$ measurements in the estuaries, the continuous $\mathrm{pCO}_{2}$ measurements were used to calculate the average $\mathrm{pCO}_{2}$ at each salinity point in the respective rivers (continuous). As the trip in the Siak river covered two days with a pause upstream, the $\mathrm{pCO}_{2}$ data is divided between 'In' and 'Out' to highlight the difference in $\mathrm{pCO}_{2}$ concentrations. During the way into the Siak the $\mathrm{pCO}_{2}$ concentrations are slightly lower than during the way out. This is presumably due to a plankton bloom that occurred as relatively low DOC concentrations allowed for enhanced light availability, which absorbed $\mathrm{CO}_{2}$ for photosynthesis ${ }^{7}$.

concentration coastal ocean waters. This linear relationship along a salinity gradient is referred to as a mixing line and represents the expected TA and DIC concentrations at a specific salinity as a consequence of mixing (Supplementary Fig. 2). Based on these TA and DIC mixing lines calculated for the Musi, Indragiri and Siak estuaries, $\mathrm{pCO}_{2}$ mixing lines were calculated using co2sys with the TA and DIC concentrations of the mixing lines as input parameters, in addition to temperature, salinity and air pressure. The $\mathrm{pCO}_{2}$ (non-linear) mixing lines represent the expected decrease in $\mathrm{pCO}_{2}$ concentrations along the salinity gradient caused by mixing and are visualized along with the measured $\mathrm{pCO}_{2}$ concentrations for the Musi, Indragiri and Siak estuaries in Fig. $2 \mathrm{~b}$. The $\mathrm{pCO}_{2}$ mixing lines are initially relatively high in accordance with the measurements, but quickly decrease exponentially. However, the higher $\mathrm{pCO}_{2}$ measurements indicate that additional $\mathrm{CO}_{2}$ is produced that increases the $\mathrm{pCO}_{2}$ beyond the level expected during mixing. This confirms the general observation that especially the estuaries are heterotrophic systems, where respiration and decomposition of organic carbon are dominant processes. The $\delta^{13} \mathrm{C}_{\text {DIC }}$ data (Fig. 2a) shows the influence of terrestrial carbon in the estuaries and coastal ocean. However, its increase with increasing salinity is in a linear fashion, thereby seemingly due to mixing. Decomposition of terrestrial organic carbon would result in more negative values, expressed in a curve below the observed linear correlation. On the other hand, outgassing of $\mathrm{CO}_{2}$ at a $\mathrm{pCO}_{2}$ twice or more that of the atmosphere raises the $\delta^{13} \mathrm{C}_{\mathrm{DIC}}$ values ${ }^{20}$, providing a curve above the observed correlation. Both processes occur in the estuaries and balance the resulting $\delta^{13} \mathrm{C}_{\mathrm{DIC}}$ values to appear linear.

In order to quantify how much of the respired exported carbon is emitted as $\mathrm{CO}_{2}$ to the atmosphere, the $\mathrm{CO}_{2}$ yields of the estuaries and coastal ocean were calculated and amount to $670.7 \pm 98.4 \mathrm{~g} \mathrm{C} \mathrm{m}^{-2} \mathrm{yr}^{-1}$ and $49.4 \pm 7.2 \mathrm{~g} \mathrm{C} \mathrm{m}^{-2} \mathrm{yr}^{-1}$, respectively (Table 2). Multiplied by their surface areas, this results in a $\mathrm{CO}_{2}$ flux of $7.3 \pm 1.1 \mathrm{Tg} \mathrm{C} \mathrm{yr}^{-1}$ in the estuaries and $6.3 \pm 0.9 \mathrm{Tg} \mathrm{C} \mathrm{yr}^{-1}$ in the coastal ocean. This finding is contradictory to a recent study that predicts the coastal ocean of Southeast Asia to be a carbon sink ${ }^{21}$. Whereas this may be the case for the northern part of Southeast Asia from where this data point is extrapolated due to data scarcity, our data shows that the coastal ocean of Sumatra is instead a carbon source. Indeed, it appears that the short residence time of the rivers creates relatively modest $\mathrm{CO}_{2}$ emissions in the rivers with $16.5{\mathrm{Tg} \mathrm{C} \mathrm{yr}^{-1} \text { in Sumatra }}^{7}$, but in fact shifts this process of $\mathrm{CO}_{2}$ emission to the estuaries and coastal ocean where the exported organic carbon is 


\begin{tabular}{|l|l|l|l|l|}
\hline \multicolumn{2}{|l|}{ Location } & Estuaries & Coastal ocean & Subtotal marine \\
\hline Area & $\mathrm{km}^{2}$ & 10818 & 127674 & 138492 \\
\hline Wind speed & $\mathrm{m} / \mathrm{s}$ & $5.59 \pm 0.41$ & $5.59 \pm 0.41$ & $/$ \\
\hline $\mathrm{K}_{\mathrm{W}}$ & $\mathrm{cm} \mathrm{hr}$ & $12.0 \pm 1.8$ & $12.0 \pm 1.8$ & $/$ \\
\hline $\mathrm{pCO}_{2}$ conc. & $\mu \mathrm{atm}$ & $2038 \pm 56$ & $554 \pm 1$ & $/$ \\
\hline $\mathrm{CO}_{2}$ yield & $\mathrm{g} \mathrm{C} \mathrm{m}^{-2} \mathrm{yr}^{-1}$ & $670.7 \pm 98.4$ & $49.4 \pm 7.2$ & $/$ \\
\hline $\mathrm{CO}_{2}$ flux & $\mathrm{Tg} \mathrm{yr}^{-1}$ & $7.3 \pm 1.1$ & $6.3 \pm 0.9$ & $13.6 \pm 2.0$ \\
\hline
\end{tabular}

Table 2. $\mathrm{CO}_{2}$ outgassing fluxes of the rivers, estuaries and coastal ocean of Sumatra based on averaged concentrations measured during expeditions from 2009 to 2013. Errors are represented as the standard error. K is based on Wanninkhof. The spread of the $\mathrm{K}_{\mathrm{W}}, \mathrm{CO}_{2}$ yields and fluxes are best/worst case scenarios, calculated based on the s.d. of the wind speed. The spread of the $\mathrm{pCO}_{2}$ is the s.e.
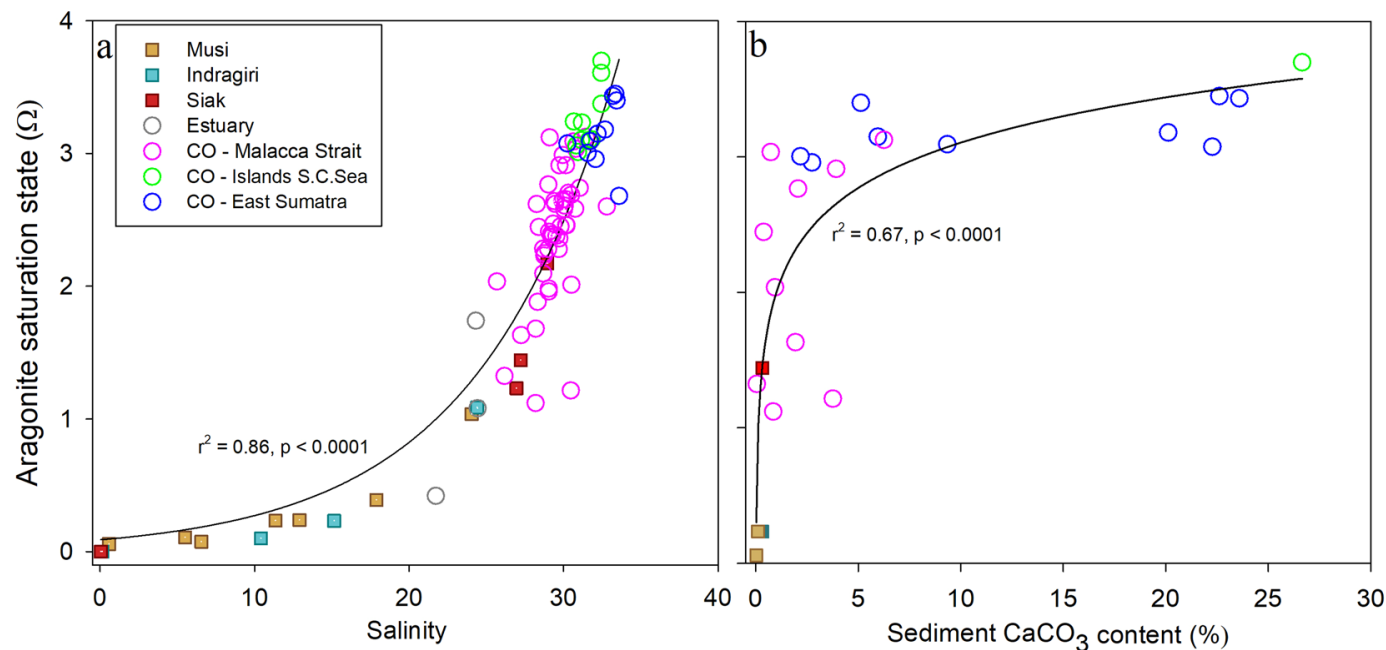

Figure 3. (a) Aragonite saturation states against salinity for the estuaries, coastal ocean and three regions of the coastal ocean of Sumatra: Malacca Strait, Tudjuh Islands and East Sumatra. (b) Correlation between the aragonite saturation states and sediment $\mathrm{CaCO}_{3}$ content.

respired, thereby causing a combined $\mathrm{CO}_{2}$ emission of $13.6 \pm 2.0 \mathrm{Tg} \mathrm{C} \mathrm{yr}^{-1}$. In regard to the total carbon export of 21.6 $\mathrm{Tg} \mathrm{C} \mathrm{yr}^{-1}$, this suggests that the excess of $8.0 \mathrm{Tg} \mathrm{C} \mathrm{yr}^{-1}$ is either exported into the sediments or it is adsorbed by marine waters. Although actual sedimentation rates are uncertain, globally it is estimated that approximately $10 \%$ of the exported terrestrial organic carbon is sequestered in continental margin sediments ${ }^{22}$. Assuming a similar burial rate for Sumatra and its TOC export of $15.6 \mathrm{Tg} \mathrm{C} \mathrm{yr}^{-1}$, this results in a sedimentation rate of $1.6 \mathrm{Tg} \mathrm{C}$ $\mathrm{yr}^{-1}$, which would reduce the excess of exported carbon from 8.0 to $6.4 \mathrm{Tg} \mathrm{C} \mathrm{yr}^{-1}$. The remaining excess of carbon may be partially exported to the open ocean ${ }^{23}$, but is most presumably further remineralized to form $\mathrm{CO}_{2}\left(\right.$ ref. $\left.^{24}\right)$. In addition to the exported $\mathrm{DIC}_{\mathrm{CO} 2}$, this may be used for photosynthesis or alternatively is absorbed by marine waters through carbonate dissolution, which shifts the carbonate system towards lower $\mathrm{CO}_{2}$ concentrations.

Carbonate dissolution. Marine organisms primarily use two major forms of $\mathrm{CaCO}_{3}$, namely aragonite (corals and many mollusks) and calcite (coccolithophores, foraminifera and some mollusks) ${ }^{25}$. The saturation states of aragonite $\left(\Omega_{\mathrm{AR}}\right)$ and calcite $\left(\Omega_{\mathrm{CA}}\right)$, calculated using co2sys with TA and $\mathrm{pCO}_{2}$ as input parameters, found in the Sumatran estuaries range between $0-1.1$, which encourages carbonate dissolution ${ }^{25}$ and hampers the growth of carbonate-producing organisms. In the coastal ocean, the values increase up to 3.5 for $\Omega_{\mathrm{AR}}$ and 5.5 for $\Omega_{\mathrm{CA}}$ (Fig. 3a and Supplementary Fig. 2, respectively). This gradient from the estuaries to the coastal ocean is notably reflected by the mollusk species richness and abundance, which is correlated to the sediment carbonate weight content ${ }^{26}$. Indeed, the minor sediment carbonate content in the river mouths $(0-4 \%)$ and Malacca Strait $(<1 \%)$ allow few mollusk species to thrive with very low abundance, whereas the increased carbonate content in East Sumatra (2-79\%) and the Tuju Islands (27-92\%) show increased species richness and mollusk abundance ${ }^{26}$. The sediment carbonate content is also correlated to the $\Omega$, where the increase of carbonate content is translated in a relatively quick increase in $\Omega_{\mathrm{AR}}$ and stabilizes between 3 and 4 as the carbonate content reaches beyond 25\% (Fig. 3b). Nonetheless, taking into account that calcification rates and cementation sharply decrease at $\Omega_{\mathrm{AR}}<4\left(\right.$ ref. $\left.^{27}\right)$ and $\Omega_{\mathrm{AR}}<3\left(\right.$ ref. $\left.^{28}\right)$, respectively, the findings indicate that calcification rates in the coastal ocean are not optimal. In order to visualize the balance between $\mathrm{CaCO}_{3}$ dissolution and formation, the measured total alkalinity (TA) and DIC concentrations were compared to their respective mixing lines (Supplementary Figs 3 and 4). The DIC and TA deviations were then plotted against each other to visualize their ratio, which sheds light on the occurring processes (Fig. 4). In accordance with their low $\Omega_{\mathrm{AR}}$, most of the estuarine data points show the largest dissolution and are offset to the right due to additional DIC in 


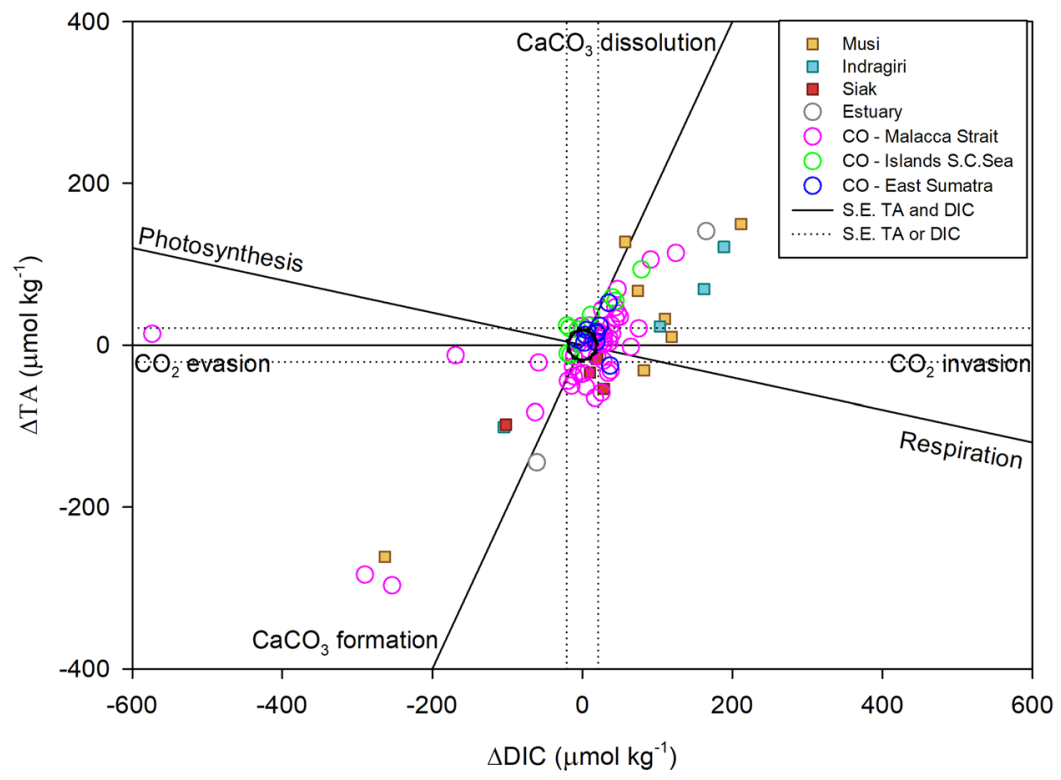

Figure 4. Deviations of DIC and TA for the Musi, Indragiri and Siak estuaries, as well as other estuaries and the coastal ocean. The black solid lines show the processes that occur corresponding to the ratio of increase or decrease of DIC and TA, namely photosynthesis/respiration, $\mathrm{CO}_{2}$ invasion/evasion and $\mathrm{CaCO}_{3}$ formation/ dissolution. Data points within the black standard error (s.e.) circle have no significant deviations for both TA or DIC and indicate the process of mixing, whereas the direction and degree of deviation away from the s.e. circle point to other processes as indicated by the black solid lines in the plot. Data points in between lines show a mixture of the neighboring processes. Modified after Zeebe \& Wolf-Gladrow (2001).

the form of respired $\mathrm{CO}_{2}$. This confirms our previous observation that, besides $\mathrm{CaCO}_{3}$ dissolution as evident from this plot and the $\Omega_{\mathrm{AR}} / \Omega_{\mathrm{CA}}$, respiration is an active process in the estuaries. Whereas optimal $\Omega_{\mathrm{AR}}$ and $\Omega_{\mathrm{CA}}$ conditions in the coastal ocean would result in its data points along the $\mathrm{CaCO}_{3}$ formation, the cluster is shifted toward dissolution instead, with an offset towards respiration. This indicates that ocean acidification as a consequence of oversaturation of respired $\mathrm{CO}_{2}$ is taking its toll in the coastal ocean as well, through reduced calcification rates, but also carbonate dissolution. Although the carbonate source for dissolution in the estuaries consists of sediment and benthic calcifying organisms, such as mollusks, it may also affect coral reefs located a bit further out the coast as the situation persists or aggravates. Indeed, whereas a simultaneous study revealed global reefs situated in the open ocean to show net carbonate formation ${ }^{29}$, a patch at the northwestern tip of Sumatra was recently identified as 'dark spot', distinguished by intensive fishing technologies, but also environmental shocks such as coral bleaching ${ }^{30}$. In addition, a recent survey in the coastal ocean of Sumatra has revealed that the status of coral reefs at $81 \%$ of 75 clustered survey stations (Fig. 1) is fair to bad, meaning that less than $50 \%$ of the corals is alive $\mathrm{e}^{31}$, although the precise cause for this status is uncertain. However, knowing that ocean acidification, which lowers the saturation states, may cause coral bleaching and productivity $\operatorname{loss}^{32}$, and seeing that the surveys were at the outskirts of the study area, coral reefs and other calcifying organisms closer to the coast may be in even worse condition and are at a higher risk to bleaching, reduced calcification rates and dissolution caused by lowered saturation states as a consequence of enhanced riverine carbon inputs, as already apparent in the mollusk assemblages ${ }^{26}$. The disappearance of carbonate-producing reef organisms would have vast ecological and economic impacts as the trophic system becomes disturbed, thereby affecting biodiversity, sediment production and sequestration, in addition to destabilization of the coast ${ }^{33}$.

The invisible carbon footprint. In Sumatra $62.7 \%$ of the exported total carbon (13.6 of $\left.21.6 \mathrm{Tg} \mathrm{yr}^{-1}\right)$ is emitted from the estuaries and coastal ocean and $10 \%$ of its organic carbon export is assumed to be sequestered in the sediments. Adopting similar emission and burial percentages for entire Indonesia with its total carbon export of 78.8 $\mathrm{Tg} \mathrm{C} \mathrm{yr}^{-1}$ and organic carbon export of 53.1 $\mathrm{Tg} \mathrm{C} \mathrm{yr}^{-1}$, the $\mathrm{CO}_{2}$ emissions from the estuaries and coastal ocean result in a total of $49.4 \mathrm{Tg} \mathrm{C} \mathrm{yr}^{-1}$ with another $5.3 \mathrm{Tg} \mathrm{C} \mathrm{yr}^{-1}$ buried in the sediments (Fig. 5). The remaining exported carbon of $24.1 \mathrm{Tg} \mathrm{C} \mathrm{yr}^{-1}(30.6 \%)$ remains in the marine waters where it further respires and favors $\mathrm{CaCO}_{3}$ dissolution by lowering the saturation states. As saturation states are lowered by inputs of $\mathrm{Ca}^{2+}$-poor and acidic freshwater, this situation is induced by the peatlands, which overlie mineral soils thereby reducing weathering, and moreover produce an acidic $\mathrm{CO}_{2}$-rich environment through decomposition of leached organic carbon in the rivers that extends into the estuaries and beyond. Having greatly increased DOC leaching from peat soils through degradation by $200 \%$ as compared to the natural situation ${ }^{5}$, anthropogenic disturbance may therefore be seen as a primary contributor to the low saturation states in the estuaries and, to a lesser extent, the coastal ocean. The respired carbon that remains in the ocean and favors carbonate dissolution can therefore be viewed as the invisible carbon footprint induced by LUC, which should be considered in terms of ocean acidification. UNESCO already recognizes ocean acidification as a serious threat and urges the UNFCCC to consider its negative effects on the ocean chemistry and marine ecosystem ${ }^{34}$. In addition, the UN Sustainable Development Goal 14 'Life 


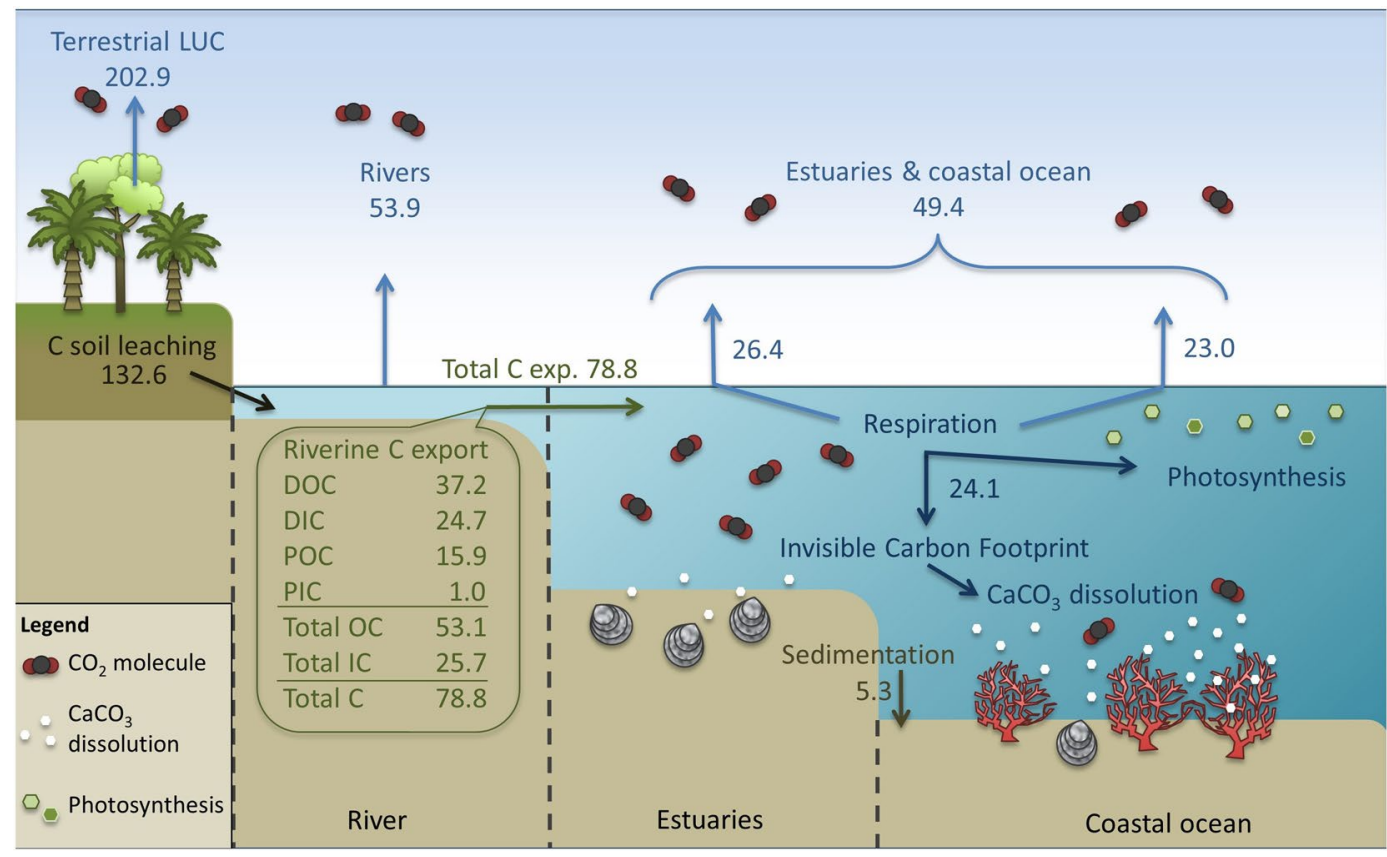

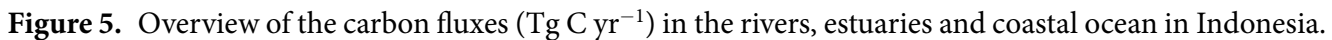
With the exception of the terrestrial LUC emissions, all fluxes include a portion of the natural indirect

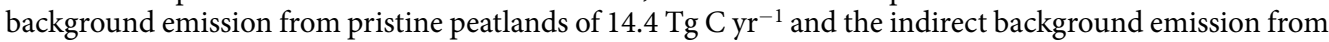

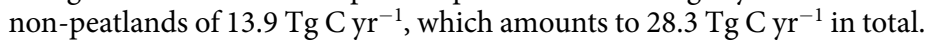

below water' ${ }^{35}$ aims to sustainably use marine resources and address the impact of ocean acidification. However, whereas this study shows that the effects of LUC stretch beyond the terrestrial realm, the invisible carbon footprint is currently overlooked in mitigation policies alongside the $\mathrm{CO}_{2}$ emissions from the rivers, estuaries and coastal ocean, as the focus is on reducing direct terrestrial carbon emissions ${ }^{36-38}$.

In Southeast Asia, approximately $6 \%$ of the peatlands remain pristine, whereas $11 \%$ is covered by disturbed (secondary) vegetation, $2 \%$ is (seasonal) water surface and $81 \%$ is degraded and converted peatland cover ${ }^{14}$. Assuming an even distribution, a peatland cover of $2.3 * 10^{5} \mathrm{~km}^{2}$ and a yield of $433 \mathrm{~g} \mathrm{C} \mathrm{m}^{-2} \mathrm{yr}^{-1}$ (ref. ${ }^{4}$ ), the direct terrestrial $\mathrm{CO}_{2}$ emission from secondary vegetation in Indonesia amounts to $10.9 \mathrm{Tg} \mathrm{C} \mathrm{yr}^{-1}$. Its direct terrestrial $\mathrm{CO}_{2}$ emissions due to LUC via peat oxidation and fires from the degraded and converted peatland cover result in $109.9 \mathrm{Tg} \mathrm{yr}^{-1}\left(\mathrm{ref}^{39}\right)$

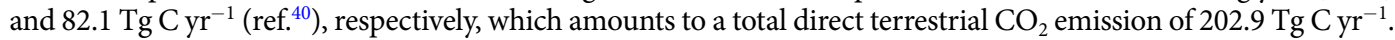
Carbon loss due to indirect aquatic emissions from the rivers $53.9 \mathrm{Tg} \mathrm{yr}^{-1}$, (ref. ${ }^{7}$ ), estuaries and coastal ocean (49.4

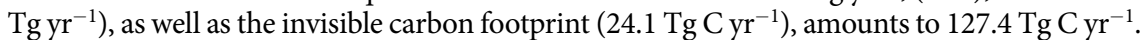

However, this value still includes the natural background indirect emissions from pristine peatland and non-peatlands. The natural indirect peatland emission can be deduced from the TOC leaching rate of pristine peatlands of $63 \mathrm{~g} \mathrm{C} \mathrm{m}^{-2} \mathrm{yr}^{-1}$ (ref. ${ }^{6}$ ) and amounts to $14.4 \mathrm{Tg} \mathrm{C} \mathrm{yr}^{-1}$. The indirect emission from non-peatland (1.7 $* 10^{6} \mathrm{~km}^{2}$ ) is deduced from the correlation with peat coverage and DOC, where a peat coverage of $0 \%$ results in a DOC leaching of $5.6 \mathrm{~g} \mathrm{C} \mathrm{m}^{-2} \mathrm{yr}^{-1}$ or $9.5 \mathrm{Tg} \mathrm{C} \mathrm{yr}^{-1}$. POC values vary per river in a non-correlating fashion, but POC exports consist on average of $45 \%$ of the DOC export, resulting in an indirect POC leaching rate of $2.6 \mathrm{gC}$ $\mathrm{m}^{-2} \mathrm{yr}^{-1}$ or $4.4 \mathrm{TgC}^{-1}$ with a TOC emission from non-peatland of $13.9 \mathrm{Tg} \mathrm{C} \mathrm{yr}^{-1}$.

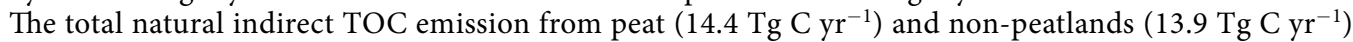
amounts to $28.3 \mathrm{Tg} \mathrm{C} \mathrm{yr}^{-1}$. Subtracting the natural indirect emission of $28.3 \mathrm{Tg} \mathrm{C} \mathrm{yr}^{-1}$ from the current one of 127.4 $\mathrm{Tg} \mathrm{C} \mathrm{yr}^{-1}$ results in a total indirect LUC emission of $99.1 \mathrm{Tg} \mathrm{C} \mathrm{yr}^{-1}$. This indicates that LUC has not only increased soil DOC leaching by $200 \%{ }^{5}$ but also POC leaching, which leads to increased soil TOC leaching or indirect emissions by $350 \%$ as compared to the natural situation.

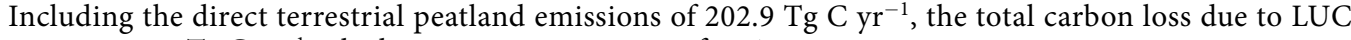

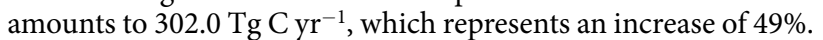

Considering this large impact along with the environmental and economic effects on global climate and the marine ecosystem, it is of vital importance that LUC mitigation policies are not only limited to direct terrestrial greenhouse gas emissions, but also incorporate the aquatic and marine $\mathrm{CO}_{2}$ emissions as well as the invisible carbon footprint.

\section{Methods}

Climate study area. Sumatra is subject to the Malaysian-Australian monsoon as a consequence of the meridional variation of the intertropical convergence zone. During the wet season, which lasts from October to April, the monsoon brings heavy rains from the north, whereas from May to September dry air currents from Australia induce a dry season ${ }^{41}$. Precipitation rates vary between $123 \mathrm{~mm}$ in July to $312 \mathrm{~mm}$ in November with an annual sum of 2,696 mm in Pekanbaru, Central Sumatra ${ }^{42}$. 
Sampling methods. Salinity, $\mathrm{pCO}_{2}$ and temperature were measured continuously by means of underway instruments, which were connected via a through-flow system and supplied with surface water from an approximate depth of $1 \mathrm{~m}$. Salinity was measured using a Seabird SBE 45 Micro TSG sensor, whereas temperature was measured via the integrated sensor of the Meinsberg EGA 140 SMEK pH sensor. $\mathrm{pCO}_{2}$ measurements were carried out with a Li-Cor 7,000 $\mathrm{pCO}_{2}$ analyzer in 2009 and 2012, and a Contros HydroC $\mathrm{CO}_{2}$ Flow Through Sensor in 2012 and 2013. Both $\mathrm{pCO}_{2}$ devices were calibrated prior to the expeditions, of which the Contros HydroC device at 100, 448 and $800 \mathrm{ppm}$. The Li-Cor 7,000 device was calibrated using certificated NOAA reference gases (\#CB08923 with $359.83 \mathrm{ppm}$, \#CA06265 with 1,021.94 ppm) and another certificated calibration gas with $8,000 \mathrm{ppm}$. Wind parameters were measured using pre-installed equipment available on the vessel in 2009 and by means of a Lambrecht Ultrasonik anemometer in 2012, both at a height of $10 \mathrm{~m}$ above sea level.

In addition to continuous measurements, water samples were taken at each station using a Niskin bottle at circa $1.5 \mathrm{~m}$ depth. After a total storage (during and after expedition) of maximum three weeks, the samples were analyzed in the laboratory in Bremen, Germany. Samples for $\delta^{13} \mathrm{C}_{\mathrm{DIC}}$ were stored in amber-colored $20 \mathrm{ml}$ bottles, deprived of air, intoxicated with mercuric chloride $\left(\mathrm{HgCl}_{2}\right)$ and analysed using the Finnigan GasBench II. In this instrument, organic compounds eluting from a GC column are converted into simple gases when traversing a capillary micro-reactor. Accordingly, all compound specific isotope ratios are analyzed in the IRMS. DOC samples were filtered $(0.45 \mu \mathrm{m})$ into $60 \mathrm{ml}$ high-density polyethylene (HDPC) bottles and acidified with phosphoric acid (20\%) up to $\mathrm{pH} 2.0$. By means of a Shimadzu TOC-VCPH Total Organic Carbon Analyzer, the samples were combusted at $680^{\circ} \mathrm{C}$ within a quartz column and the released $\mathrm{CO}_{2}$ was measured using the oxidative combustion-infrared analysis. The relative standard error for the method was $\pm 1 \%$. Alkalinity samples were collected in $250 \mathrm{ml}$ glass bottles in 2009 and 2012 and in $125 \mathrm{ml} \mathrm{LDPE}$ flasks in 2013, deprived of air, intoxicated with $\mathrm{HgCl}_{2}$ and analyzed using a VINDTA $3 \mathrm{~S}$ instrument. Known amounts of sampled seawater were titrated with constant increments of $0.15 \mathrm{ml}$ of hydrochloric acid $(\mathrm{HCl})$ until a total amount of $4.2 \mathrm{ml} \mathrm{HCl}$ was reached. The $\mathrm{HCl}$ in the device was calibrated with a sodium chloride solution to approximate the ionic strength of seawater. The process of the open cell titration allowed the assumption that the total amount of DIC was approximately zero in the $\mathrm{pH}$ region of 3.0-3.5. The process was monitored using a $\mathrm{pH}$ glass electrode cell and the total alkalinity (TA) was calculated from the titrant volume and electromotoric force using a non-linear least-squares approach that corrected for the reactions with sulphate and fluoride ions. Measurements of temperature, salinity, $\mathrm{pH}, \mathrm{pCO}_{2}$ and TA at the stations are shown in Supplementary Table 3.

$\mathrm{CO}_{2}$ flux and piston velocity calculations for estuaries and coastal ocean. $\mathrm{CO}_{2}$ fluxes (F) were calculated from the $\mathrm{pCO}_{2}$ measurements of the continuous data using:

$$
\mathrm{F}=\mathrm{K}_{\mathrm{CO} 2} \times \mathrm{K}_{0} \times \Delta \mathrm{pCO}_{2}
$$

where $\mathrm{K}_{\mathrm{CO} 2}$ is the $\mathrm{CO}_{2}$ piston velocity, $\mathrm{K}_{0}$ the solubility of $\mathrm{CO}_{2}$ in seawater ${ }^{43}$ and $\Delta \mathrm{pCO}_{2}$ is the sea-air $\mathrm{pCO}_{2}$ difference with an average atmospheric $\mathrm{CO}_{2}$ concentration of circa $390 \mathrm{ppm}$, as measured during the cruises.

Although piston velocities are affected by many processes such as surface wave types, formation of air bubbles, humidity and temperature gradients and organic film coating, in the coastal systems and ocean piston velocities are primarily influenced by wind speed and the Schmidt number ${ }^{44}$. Therefore, piston velocity calculations related to wind speed have been chosen for this study. As calculations from Wanninkhof ${ }^{45}$ and Nightingale et al. ${ }^{46}$ are widely used in the literature ${ }^{47,48}$, both formulas have been used to calculate $\mathrm{K}_{\mathrm{CO} 2}$ for comparative matters. $\mathrm{CO}_{2}$ calculations based on Wanninkhof's principles were 9.2\% higher than Nightingale's and are used to represent a maximum estimate, which results in a lower invisible carbon footprint. The results based on Nightingale's principle are summarized in Supplementary Table 2.

$$
\begin{gathered}
\mathrm{K}_{\mathrm{W} 92}=0.31 * \mathrm{U}^{2} *(\mathrm{Sc} / 600)^{-0.5} \\
\mathrm{~K}_{\mathrm{N}}=\left(0.222 * \mathrm{U}^{2}+0.333 * \mathrm{U}\right) *(\mathrm{Sc} / 600)^{-0.5}
\end{gathered}
$$

where $\mathrm{K}_{\mathrm{W} 92}$ and $\mathrm{K}_{\mathrm{N}}$ are the formulas for Wanninkhof and Nightingale, respectively. $\mathrm{U}$ is wind speed in $\mathrm{m} \mathrm{s}^{-1}$ at a height of $10 \mathrm{~m}$ above sea level and $\mathrm{Sc}$ is the Schmidt number for $\mathrm{CO}_{2}$ (kinematic viscosity of water divided by the diffusion coefficient of $\mathrm{CO}_{2}$ in water) in seawater determined for temperatures between 0 and $30^{\circ} \mathrm{C}^{45}$ calculated by:

$$
\mathrm{Sc}=2073.1+-125.62 * \mathrm{~T}+3.6276 * \mathrm{~T}^{2}+-0.043219 * \mathrm{~T}^{3}
$$

where $\mathrm{T}$ is temperature in ${ }^{\circ} \mathrm{C}$. Although wind speed was measured during the cruises in 2009 and 2012 with averages of $2.39 \pm 0.01 \mathrm{~m} \mathrm{~s}^{-1}$ and $3.97 \pm 0.02 \mathrm{~m} \mathrm{~s}^{-1}$, respectively. However, the annual wind speed derived from QuikSCAT ${ }^{49}$ by averaging monthly measurements between 2001 and 2008 within the coastal ocean area (Fig. 1) resulted in an annual average wind speed of $5.59 \pm 0.41 \mathrm{~m} \mathrm{~s}^{-1}$. Therefore, the QuickSCAT average was used to get a maximum estimate on emissions.

Surface area calculations. Catchment areas were defined by means of a relief model in ArcGIS 9.3 with the ArcHydro extension, which was derived from SRTM90m digital elevation model of the Consortium for Spatial Information of the Consultative Group for International Agricultural Research (CGIAR-CSI). Peat coverage in each catchment was determined by overlaying the determined catchment areas by the FAO soil map of the world ${ }^{16}$. The peat coverage for Sumatra was derived from Miettinen et al. ${ }^{12}$. 
Generally, the border between estuaries and coastal ocean is predetermined at a salinity equal to or more than $30^{50}$. However, in this study the correlation between salinity and the aragonite saturation state off the coast of Sumatra shows a clear distinction of this border, indicated by $\Omega_{\mathrm{AR}}$ values of $\leq 1$ below salinity 25 , and a rapid increase of $\Omega_{\mathrm{AR}} \geq 1$ at salinities $\geq 25$ (Fig. 3a). Therefore, the border between estuaries and coastal ocean is here defined at a salinity equal to or higher than 25 . By correlating the salinity and distance to shore, this border is found at an approximate distance of $3 \mathrm{~km}$ (Supplementary Fig. 5). Based on this distance, the surface area of the estuaries was estimated using ArcGIS 10.4 and, assuming that estuaries influence the entire coastline, amounts to $10,818 \mathrm{~km}^{2}$. The perimeter of the coastal ocean is based on the correlation between salinity and $\delta^{13} \mathrm{C}$, where the terrestrial influence, characterized as $\delta^{13} \mathrm{C}$ values below the marine $\delta^{13} \mathrm{C}$ signature of circa $+1 \%$ (ref. ${ }^{51}$ ), reached up to a salinity of circa 32.8 (Fig. 2a). This salinity coincided with a distance of circa $67 \mathrm{~km}$, which resulted in a surface area of $127,674 \mathrm{~km}^{2}$.

Calibration experiment. As $\mathrm{pCO}_{2}$ was measured with different devices in 2009 and $2013, \mathrm{a} \mathrm{CO}_{2}$ calibration experiment was conducted to validate the Contros measurements, during which different concentrations of $\mathrm{CO}_{2}$ gas were delivered using a gas mixing system. The gas concentrations delivered by the gas mixing system were first monitored and compared by the mixing system regulator, the Li-Cor 7000, the Li-820 and the cavity ring-down spectrometer (Picarro G2201-i) in a range from circa 500 to $6000 \mathrm{ppm}$ (Supplementary Fig. 6a). The gas was then used to calibrate seawater in a range of 500-5000 ppm that was pumped into the Li-Cor 7000 equilibrator and the Contros sensor. The measured $\mathrm{pCO}_{2}$ concentrations were highly correlated (Supplementary Fig. 6b), especially in the lower concentration range common in the coast, which justified the Contros measurements.

Uncertainty estimates. The errors associated with the averaged parameters in the rivers, estuaries and coastal ocean are presented as the standard error (s.e.). The error range of the alkalinity is based on the standard error of the seawater standards measured during the sample analysis and applied to the respective samples. The error of DIC can be seen as best/worst case scenario, as the errors of TA and $\mathrm{pCO}_{2}$ have been integrated throughout the co2sys calculations. The error range of the $\mathrm{CO}_{2}$ yields and fluxes in the estuaries and coastal ocean are the result of the standard deviation of the piston velocities in turn as a consequence of the standard deviation of the wind speed $\left(5.59 \pm 0.41 \mathrm{~m} \mathrm{~s}^{-1}\right)$, which was integrated in the $\mathrm{CO}_{2}$ yield and flux calculations to give a best/worst case scenario.

\section{Data Availability}

The datasets generated during and/or analyzed during the current study are available from the corresponding author on reasonable request.

\section{References}

1. Page, S. E., Rieley, J. O. \& Banks, C. J. Global and regional importance of the tropical peatland carbon pool. Glob. Chang. Biol. 17 (2010).

2. Ciais, P. et al. Carbon and Other Biogeochemical Cycles. In: Climate Change 2013: The Physical Science Basis. Contribution of Working Group I to the FifthAssessment Report of the Intergovernmental Panel on Climate Change. https://doi.org/10.1017/ CBO9781107415324.015 (2013).

3. Houghton, R. A. et al. Carbon emissions from land use and land-cover change. Biogeosciences 9, 5125-5142 (2012).

4. Hirano, T. et al. Carbon dioxide balance of a tropical peat swamp forest in Kalimantan, Indonesia. Glob. Chang. Biol. 13, 412-425 (2007).

5. Rixen, T., Baum, A., Wit, F. \& Samiaji, J. Carbon Leaching from Tropical Peat Soils and Consequences for Carbon Balances. Front. Earth Sci. 4 (2016).

6. Moore, S. et al. Deep instability of deforested tropical peatlands revealed by fluvial organic carbon fluxes. Nature 493, 660-3 (2013).

7. Wit, F. et al. The impact of disturbed peatlands on river outgassing in Southeast Asia. Nat. Commun. 6(10155), 1-9 (2015).

8. Borges, A. V., Delille, B. \& Frankignoulle, M. Budgeting sinks and sources of CO2 in the coastal ocean: Diversity of ecosystems counts. Geophys. Res. Lett. 32, 1-6 (2005).

9. Chen, C. A. et al. Air - sea exchanges of CO2 in the world's coastal seas. Biogeosciences 10, 6509-6544 (2013).

10. Cai, W. Estuarine and Coastal Ocean Carbon Paradox: CO2 Sinks or Sites of Terrestrial Carbon Incineration? Ann. Rev. Mar. Sci. 3, 123-145 (2011).

11. Laruelle, G. G., Lauerwald, R., Pfeil, B. \& Regnier, P. Regionalized global budget of the CO2 exchange at the air-water interface in continental shelf areas. Global Biogeochem. Cycles 28, 1199-1214 (2014).

12. Miettinen, J. et al. Historical Analysis and Projection of Oil Palm Plantation Expansion on Peatland in Southeast Asia. Int. Counc. Clean Transp. 22 (2012).

13. Hooijer, A., Silvius, M., Wösten, H. \& Page, S. E. PEAT-CO2, Assessment of CO2 emissions from drained peatlands in SEAsia. Delft Hydraul. Rep. Q3943 (2006).

14. Miettinen, J., Shi, C. \& Liew, S. C. Land cover distribution in the peatlands of Peninsular Malaysia, Sumatra and Borneo in 2015 with changes since 1990. Glob. Ecol. Conserv. 6, 67-78 (2016).

15. Huang, T., Fu, Y., Pan, P. \& Chen, C. A. Fluvial carbon fluxes in tropical rivers. Curr. Opin. Environ. Sustain. 4, 162-169 (2012).

16. FAO/UNESCO. Digital soil map of the world and derived soil properties. (2004).

17. Polsenaere, P. \& Abril, G. Modelling CO2 degassing from small acidic rivers using water pCO2, DIC and $\delta 13 \mathrm{C}-\mathrm{DIC}$ data. Geochim. Cosmochim. Acta 91, 220-239 (2012).

18. Schindlbacher, A. et al. Contribution of carbonate weathering to the CO2 efflux from temperate forest soils. Biogeochemistry 124, 273-290 (2015).

19. Richey, J. E., Melack, J. M., Aufdenkampe, A. K., Ballester, V. M. \& Hess, L. L. Outgassing from Amazonian rivers and wetlands as a large tropical source of atmospheric CO2. Nature 416, 617-20 (2002).

20. Doctor, D. H. et al. Carbon isotope fractionation of dissolved inorganic carbon (DIC) due to outgassing of carbon dioxide from a headwater stream. 2Hydrological Process. 22, 2410-2423 (2008).

21. Laruelle, G. G. et al. Seasonal response of air-water CO2 exchange along the land-ocean aquatic continuum of the North East American coast. Biogeosciences 11985-12008 https://doi.org/10.5194/bg-12-1447-2015(2014).

22. Schlünz, B. \& Schneider, R. R. Transport of terrestrial organic carbon to the oceans by rivers: re-estimating flux and burial rates. Int. J. Earth Sci. 88, 599-606 (2000). 
23. Andersson, A. J., MacKenzie, F. T. \& Lerman, A. Coastal ocean and carbonate systems in the high CO2 world of the anthropocene. Am. J. Sci. 305, 875-918 (2005).

24. Blair, N. E. \& Aller, R. C. The Fate of Terrestrial Organic Carbon in the MarineEnvironment. Ann. Rev. Mar. Sci. 4, 401-423 (2012).

25. Doney, S. C. The Growing Human Footprint on Coastal and Open-OceanBiogeochemistry. Chang. Ocean. 328 (2010).

26. Michel, J., Wiemers, K., Samhudi, H. \& Westphal, H. Molluscan assemblages under the influence of peat-draining rivers off East Sumatra, Indonesia. Molluscan Res. 35, 81-94 (2015).

27. Langdon, C. \& Atkinson, M. J. Effect of elevated pCO2 on photosynthesis and calcification of corals and interactions with seasonal change in temperature/irradiance and nutrient enrichment. J. Geophys. Res. C Ocean. 110, 1-16 (2005).

28. Manzello, D. P. et al. Poorly cemented coral reefs of the eastern tropical Pacific: Possible insights into reef development in a highCO2 world. Pnas 105, 10450-10455 (2008).

29. Cyronak, T. et al. Taking the metabolic pulse of the world's coral reefs. 1-17 (2018).

30. Cinner, J. E. et al. Bright spots among the world's coral reefs. Nature 535, 416-432 (2016).

31. Muhammad, G. et al. Indonesian coral reef status in 2017. (2017).

32. Anthony, K. R. N., Kline, D. I., Diaz-Pulido, G., Dove, S. \& Hoegh-Guldberg, O. Ocean acidification causes bleaching and productivity loss in coral reef builders. Proc. Natl. Acad. Sci. USA 105, 17442-17446 (2008).

33. Bunkley-Williams, L. \& Williams, E. H. Global Assault on Coral Reefs. Natural History 4, 46-54 (1990).

34. UNESCO. Implement Urgent Actions to Mitigate and Adapt to Ocean Acidification. Available at: http://www.unesco.org/new/en/ natural-sciences/ioc-oceans/focus-areas/rio-20-ocean/10-proposals-for-the-ocean/1a-ocean-acidification/ (2017).

35. UN. Development Goal 14. Available at: http://www.un.org/sustainabledevelopment/oceans/ (2017).

36. Myers, E. C. Policies to Reduce Deforestation and. Bat Conserv. Int. 80 (2007).

37. Smith P. et al. Agriculture, Forestry and Other Land Use (AFOLU). In: Climate Change 2014: Mitigation of Climate Change. Contribution of Working Group III to the FifthAssessment Report of the Intergovernmental Panel on Climate Change [Edenhofer, O., R. Pichs-Madruga, Y. (Cambridge University Press, 2014).

38. UNFCCC. FOCUS: Mitigation - Action on mitigation: Reducing emissions and enhancing sinks. (2017).

39. Hooijer, A. et al. Current and future CO2 emissions from drained peatlands in Southeast Asia. Biogeosciences 7, 1505-1514 (2010).

40. van der Werf, G. R. et al. Climate regulation of fire emissions and deforestation in equatorial Asia. Proc. Natl. Acad. Sci. USA 105, 20350-5 (2008)

41. Gentilli, J., Smith, P. J. \& Krishnamurti, T. N. Malaysian-Australian monsoon. Encyclopaedia Britannica. Available at: www. britannica.com/science/Malaysian-Australian-monsoon. (2014)

42. Schwarz, T. Climate-Data. (2014).

43. Zeebe, R. E. \& Wolf-Gladrow, D. A. In CO2 in Seawater: Equilibrium, kinetics, isotopes. (2001).

44. Sarmiento, J. L. \& Gruber, N. Ocean Biogeochemical Dynamics. (2005).

45. Wanninkhof, R. Relationship between wind speed and gas exchange over the ocean. J. Geophys. Res. Ocean. 97, 7373-7382 (1992).

46. Nightingale, P. D. et al. In situ evaluation of air-sea gas exchange parameterizations using novel conservative and volatile tracers. Global Biogeochemical Cycles 14, 373-387 (2000).

47. Takahashi, T. et al. Climatological mean and decadal change in surface ocean pCO2, and net sea-air $\mathrm{CO} 2$ flux over the global oceans. Deep Sea Res. Part II Top. Stud. Oceanogr. 56, 554-577 (2009).

48. Müller, D. et al. Fate of peat-derived carbon and associated $\mathrm{CO} 2$ and CO emissions from two Southeast Asian estuaries. Biogeosciences Discussions 12 (2015)

49. Ricciardulli, L., Wentz, F. J. \& Smith, D. K. Remote Sensing Systems QuikSCAT Ku-2011 Monthly Ocean Vector Winds on 0.25 deg grid, Version 4. Remote Sensing Systems, Santa Rosa, CA Available at: www.remss.com/missions/qscat. (2011).

50. Bauer, J. E. et al. The changing carbon cycle of the coastal ocean. Nature 504, 61-70 (2013).

51. Sonnerup, R. E. \& Quay, P. D. 13C constraints on ocean carbon cycle models. Global Biogeochem. Cycles 26, 1-16 (2012).

\section{Acknowledgements}

We would like to thank all scientists and students from the University of Pekanbaru for the fieldwork assistance and the captain and crew of the Matahari-ku ship for their support. We are also grateful to the Federal German Ministry of Education, Science, Research and Technology (BMBF, Bonn grant number 03F0642-ZMT). Maps were drawn using ArcGIS 10.4 and calculations were executed with ArcGIS 10.4 and Python software, version 2.7. Graphs and schematics were made using Sigmaplot version 13 and Microsoft Powerpoint 2016, respectively.

\section{Author Contributions}

T.R. and W.S.P. designed the study. T.R. performed the Sumatra field data collection and A.B. the analysis in 2009 and F.W. performed field data collection and analysis in 2012 and 2013. F.W. led the writing of the paper. All authors discussed results and commented on the manuscript.

\section{Additional Information}

Supplementary information accompanies this paper at https://doi.org/10.1038/s41598-018-35769-7.

Competing Interests: The authors declare no competing interests.

Publisher's note: Springer Nature remains neutral with regard to jurisdictional claims in published maps and institutional affiliations.

Open Access This article is licensed under a Creative Commons Attribution 4.0 International License, which permits use, sharing, adaptation, distribution and reproduction in any medium or format, as long as you give appropriate credit to the original author(s) and the source, provide a link to the Creative Commons license, and indicate if changes were made. The images or other third party material in this article are included in the article's Creative Commons license, unless indicated otherwise in a credit line to the material. If material is not included in the article's Creative Commons license and your intended use is not permitted by statutory regulation or exceeds the permitted use, you will need to obtain permission directly from the copyright holder. To view a copy of this license, visit http://creativecommons.org/licenses/by/4.0/.

(c) The Author(s) 2018 